\title{
PHYTOPL ANKTON BIOMASS AND ENVIRONMENTAL FACTORS IN THE NOZHA HYDRODROME, ALEXANDRIA, EGYPT.
}

\section{Samiha M.Gharib}

National Institute of Oceanograph and Fisheries Kayet Bay, Alexandtia, Egypt.

Key words: Phytoplankton, Biomass,Environmental Factors Multple Regression analysis, Alexandsia

(Received may 9, 1998)

\section{ABSTRACT}

The seasonal development of phytoplankton biomass in the Nozha Hydrodrome during the period September, 1986- August, 1987 exhibited two annual peaks. The first in winter resulting from lack of nitrogen and availability of phosphorus, led to the development of $\mathrm{N}_{2}$-fixing alga Anabaenopsis circularis which averaged 11.50 and $9.14 \mathrm{mg} .1^{-1}$ for the surface and near bottom layers respectively. The second peak in spring due to the diatom Cyclotella meneghiniana (10.9 and $11.0 \mathrm{mg} .1^{-1}$ for the surface and near bottom layers, respectively). The annual averages phytoplankton biomass were 6.26 and 5.78 $\mathrm{mg} .1^{-1}$ for the two layers and lie within the range considered as characteristic of eutrophic waters. Small differences were found in the horizontal distribution and a slight increase was noticed from the western part of the hydrodrome to the east.

Results indicate that the biomass of the different classes was altered when compared with its numerical values. While Chlorophyceae was numerically the most important plankter, Cyanophyceae constituted $51.4 \%$ of the total algal biomass.

The multiple regression analysis between variations in phytoplankton biomass versus some physical and chemical parameters dealing with changes in its community illustrated excellent equations model which can be applied to predict the phytoplankton biomass in the hydrodrome. 


\section{INTRODUCTION}

The Nozha Hydrodrome is an isolated part of Lake Mariut at latitude $31^{\circ}$ 10 east and longitude $30^{\circ} \mathrm{N}$ with a total area of about 504 hectars (1200 feddans) and an average water depth $2.7 \mathrm{~m}$. The hydrodrome is constantly supplied with fresh Nile water through Mahmoudia Canal (Fig.1). The detailed morphometric features of the hydrodrome was previously given by Elster and Jensen (1960). Quantitative estimation of the phytoplankton community was carried out by Salah (1959). The distribution of hydrophytes was also given by Zaki (1960 a\&b). Further contributions on the chemistry and hydrography of the hydrodrome wer carried out by Banoub and Wahby (1961) and Saad (1973). The physical and chemical characteristics of the bottom sediments were estimated by Saad (1972 \& 1976). The periphyton community was also investigated by Samaan and Abdallah (1982). The phytoplankton community in the Nozha Hydrodrome was given by Gharib (1991), its chlorophyll $a$ was studied by El-Sherif (1989a) and the nutrient salts were discussed by Samaan et al (1994a). Dynamics of nutrient saits between bottom sediments and adjacent water was discussed by Samaan et al (1994b). The Ecology of Chlorophyceae was discussed by El- Sherif et al (1994).

This paper describes the quantitative fluctations of the phytoplankton biomass in the hydrodrome in relation to the environmental factors. Reference is made to the influence of nutrients. Statistical analysis was performed to predict the phytoplankton biomass in the hydrodrorne.

\section{MATERIAL AND METHODS}

Samples were collected monthly by Ruttner water sampler from surface and near bottom layers at seven selected stations from September, 1986 to August, 1987. The results were discussed seasonally.

The determination of the phytoplankton biomass was based on the calculation of the volume of each species from appropriate geometric formulae (Edler, 1979). The volume of algae was transformed into biomass (fresh weight) assuming that the specific gravity of the algae is one. In the present study, at least 30 individuals were measured for each species for every season and no standard cell 
Phytoplankton bimass and environmtneal factors in the Nozha Hydrodrome, Alexandria, 67

volumes were used. The rare plankters with negligible volume were excluded in this estimation.

Statistical treatment of the phytoplankton biomass versus the prevailing physico-chemical parameters for both surface and near bottom layers was performed according to the stepwise multiple regression analysis at a confidence limit of $95 \% \quad(\mathrm{P}<0.05)$ using Number Crunched Statistical System (NCSS) proposed by Hintze (1993) on a computer.

\section{Status of the hydrodrome prior to the present investigation}

The hydrodrome water was previously considered as a mesotrophic basin due to its low nutrient content and subsequently its primary productivity was also low (Salah, 1959; Aleem and Samaan, 1969). For this reason, application of fertilizers (super phosphate and ammonium sulphate or ammonium nitrate) was proposed in April, 1982 till June, 1986. These fertilizers have raised the primary productivity as well as the annual fish yield by about 4 times (Wahby \& Shraidach, 1985). In May, 1986, the concentration of nutrient salts in the water showed a sharp rise, coincided with a rapid increase of water temperature to $28^{\circ} \mathrm{C}$ caused a sudden development of undesirable bloom of blue-green algae. Accumulation of algal scums in the surface water created anoxic conditions in the subsurface layer and hydrogen sulphide was formed and causing complete oxygen consumption (Dowidar and Abdel Moati, 1989). This was followed by a mass mortality of fish in early June with a loss of about 40 tons of commercial fish. Rapid improvement of the water quality was performed through collection of all dead fish.

\section{RESULTS AND DISCUSSION}

\section{Environmental Conditions (Fig.2)}

The Nozha Hydrodrome lies in a warm temperate zone. Water temperature displays a minimum in winter $\left(14.9^{\circ} \mathrm{C}\right)$ and a maximum in summer $\left(28.3^{\circ} \mathrm{C}\right)$. The lowest transparency $(45.7 \mathrm{~cm})$ in spring may be related to the high 
phytoplankton biomass and highest was measured in winter $(76.5 \mathrm{~cm})$. PH values remained aboue 8 throughout the year, reaching 9.2 in spring and decreased to 8.7 in autumn. The maximum value of the dissolved oxygen was recorded in winter $\left(8.48 \mathrm{mlO}_{2} .1^{-1}\right)$ and the minimum was in summer $\left(4.07 \mathrm{mlO}_{2} .1^{-1}\right)$.

Concentrations of dissolved inorganic nitrogen showed marked seasonal variation. In autumn, they averaged 130.4 and $156.3 \mathrm{SgN} .1^{-1}$ for the surface and near bottom layers respectively. Ammonium constituted $46.9 \%$ and $54.2 \%$ of the total values. The concentrations of dissolved nitrogen increased gradually to reach a maximum of 579 and $671 \mathrm{sg} \mathrm{N} .1^{-1}$ for the two layers during spring, after a blooming of the $\mathrm{N}_{2}$ - fixing algae Anabaenopsis circularis. The concentrations decreased during summer.

Silica exhibited its lowest values in spring $\left(6.27\right.$ and $6.20 \mathrm{mg} \mathrm{SiO}_{2} .1^{-1}$ for the two layers respectively) probably due to the increase of diatoms and remained between 10.8 and $12.7 \mathrm{mg} \mathrm{SiO} 2.1^{-1}$ during the rest of the year.

Concentrations of reactive phosphate showed abnormal high values during autumn (2061 and $1940 \mathrm{Sg} \mathrm{PO} 4.1^{-1}$ for the two layers respectivelty) and decreased gradually to reach 81.3 and $73.7 \mathrm{Sg} \mathrm{PO}_{4} \cdot 1^{-1}$ during summer.

\section{Species composition and distribution}

Atotal of 65 taxa haves been identified in the phytoplankton in the Nozha Hydrodro me, but cell volumes of 53 species were measured and the others excluded because they were rare and with negligible volume. They were including 14 species of Cyanophyceae, 7 species of Bacillariophyceae and 27species of Chlorophyceae. Beside 4 species of Euglenophyceae and one Dinophyceae.

Cyanophyceae were the dominant group, forming $54.0 \%$ and $48.5 \%$ of the total phytoplankton biomass in the surface and near bottom layers respectively while it ranked numerically the third group whera es it formed $18.1 \%$ and $16.1 \%$ of the total phytoplankton count (Table 1). Bacillariophyceae ranked the second group $(27.3 \%$ and $32.0 \%$ of the total biomass for the surface and near bottom layers respectively). Chlorophyceae represented the third group ( $12.3 \%$ and 
Phytoplankton bimass and environmtneal factors in the Nozha Hydrodrome, Alexandria, 69

$12.6 \%$ of the total biomass for the two layers) which was numerically the dominant group as it formed about $67.0 \%$ and $68.3 \%$ of the total phytoplankton count.

Although numerous species were measured, few of them formed the main bulk of the biomass, namely; Anahaenopsis circularis which formed $83.7 \%$ and $75.2 \%$ of the total Cyanophyceae biomass in the surface annear bottom layers respectively followed by Gomphosphaeria aponina (5.9\% and 9.3\%). Cmeneghiniana formed $77.6 \%$ and $79.1 \%$ of the total Bacillariophyceae biomass in the two layers respectively, while Scenedesmus spp., Crucigenia spp., Tetraedron spp. and Chlorella vulgaris formed collectively $76.5 \%$ and $76.4 \%$ of the total Chlorophyceae biomass in the two layers respectively. All the mentioned species formed about $82 \%$ of the total phytoplankton biomass.

Observation at seven stations indicated that the hydrodrome water sustained high phytoplankton biomass in both the surface and near bottom layers which were annually amounted to 6.26 and $5.78 \mathrm{mg}^{-1} \mathrm{l}^{-1}$ respectively and are within the range considered as characteristic of eutrophic water (Vollenweider, 1968). This value is higher than that recorded in Lake Burollus (north of the Nile Delta) which amounted $2.35 \mathrm{mg} . \mathrm{I}^{-1}$ (El-Sherif, 1989b). While in Lake Nasser, it amounted $22.91 \mathrm{mg} .1^{-1}$ in the surface and $4.09 \mathrm{mg}^{-1} 1^{-1}$ in the near bottom layer (Zaghloul, 1985). Highest biomass at the surface water appeared at station II, while near bottom layer sustained more biomass at station III, both was due to Anabaenopsis circularis and Cyclotella meneghiniana (Fig.3). Phytoplankton biomass decreased westward of the hydrodrome i,e towards stations I and VII.

\section{Seasonal fluctuations of the phytoplankton biomass}

The seasonal variations of total phytoplankton biomass together with the contribution by algal groups (Fig.4) showed two biomass maxima, the first in winter amounted $11.5 \mathrm{mg} .1^{-1}$ in the surface and $9.14 \mathrm{mg}^{-1} 1^{-1}$ in the near bottom layer corresponding to Chlorophyll $a 17.4$ and $17.3 \mathrm{mg} \cdot \mathrm{m}^{-3}$ for the two layers (ElSherif, 1989b) as shown in Fig.(5). The most important species was Anabaenopsis circularis $\left(6,828 \times 10^{3}\right.$ and $4,701 \times 10^{3}$ trichome. $\left.1^{-1}\right)$ having an average volume of 
$1240 \mathrm{~mm}^{3} \times 10^{-9}$ per trichome. It contributed $94.0 \%$ and $87.2 \%$ to the bluegreen biomass and $73.6 \%$ and $63.7 \%$ to the total phytoplankton biomass. At the same time the blue-green algae represented about $78.3 \%$ and $73.0 \%$ to the phytoplankton biomass. The lack of nitrogen and the availability of phosphorus led to the development of $\mathrm{N}_{2}$-fixing algae which formed the higher phytoplankton biomass in winter (Fig.6).

Results indicated that low total N:P ratio (1:3.6) in winter is symptomatic of blue-green algal blooms in eutrophic lakes and $\mathrm{N}$ is considered a growth limiting nutrient as mentioned by Lund 1965; Claesson and Ryding 1977 and Canfield et al 1989. Also Smith (1983) proposed that the relative contribution of blue-green algae to total phytoplankton biomass is not dependent on absolute nutrient concentrations, but rather on the ratio (by weight) of total nitrogen (TN) to total phosphorus (TP) (TN/TP).

The second peak in spring resulting mainly of diatoms which amounted $5.35 \mathrm{mg} .1^{-1}$ in the surface and $5.63 \mathrm{mg} \cdot 1^{-1}$ in the near bottom layer corresponding to Chlorophyll $a 15.3 \mathrm{mg} \cdot \mathrm{m}^{-3}$ in the surface and $15.8 \mathrm{mg} \cdot \mathrm{m}^{-3}$ in the near bottom layer (El-Sherif,1983a) as shown in Fig.(5). The most important species of diatoms were Cyclotella meneghiniana and Nitzschia palea. Cyclotella meneghiniana $\left(1,853 \times 10^{3}\right.$ and $1,954 \times 10^{3}$ cell. $\left.1^{-1}\right)$ having an average volume of $2435 \mathrm{~mm}^{3} \times 10^{-9}$ per cell. It contributed $84.3 \%$ and $84.5 \%$ to the diatoms biomass and $41.5 \%$ and $43.3 \%$ to the total biomass in the surface and near bottom layers respectively. Nitzschia palea $\left(2298 \times 10^{3}\right.$ and $2700 \times 10^{3}$ cell.1 $\left.1^{-1}\right)$ having an average volume of $287 \mathrm{~mm}^{3} \times 10^{-9}$ per cell. It contributed $12.3 \%$ and $13.8 \%$ to the diatoms biomass and $6.1 \%$ and $7.1 \%$ to the total biomass in the surface and near bottom layers respectively. At the same time the diatoms represnted $49.2 \%$ and $51.2 \%$ of the phytoplankton biomass. This vernal peak coincided with a drop in silica concentration (about $6.25 \mathrm{mg} \mathrm{SiO} 2.1^{-1}$ ) as showen in Fig. (7) and availability of nitrogen (579 and 671 $\left.\mathrm{SgN} .1^{-1}\right)$. Many studies (see. e.g. Lund,1955; Hutchinson, 1967; Bailey- Watis, 1976) have indicated strong causal interactions between silica concentration and diatom abundance. At the same time, the bluegreen algae represented about $34.7 \%$ and $32.5 \%$ of the vernal peak and Anabcenopsis circularis formed $72.4 \%$ and $67.1 \%$ to the blue-green biomass. Lowest phytoplankton biomass was observed during autumn and summer (Fig.4). 
Phytoplankton bimass and environmeneal factors in the Nozha Hydrodrome, Alexandria, 71

Statistical regression analysis were calculated according to Hintze (1993) dealing with phytoplankton biomass and the most effective physico-chemical parameters at both surface

$(\mathrm{S})$ and near bottom layers (B) as follows:

\section{Surface water (S):}

Phytoplankton biomass $\left(\mathrm{mg} .1^{-1}\right)=56.07-1.52$ tenp. -0.298 Secchi disc $(r=0.81)$

\section{Near bottom water layer (B)}

Phytoplankton biomass (mg..$\left.^{-1}\right)=26.18-0.82$ tevp. -0.341 p04temp40. $(r=0.68)$

These models are adequate at a significant level 95\% ( $>00.05)$. Comparison of observed and calculated values for the two depths (Fig.8), showed a small average error due to the interference of other factors not incoporated in the model equation. The equation model reflect that the temperature was the most effective environmental factor controlling phytoplankton biomass at the two levels, beside transparency in the surface water. Reactive phosphate had also an effect at the near bottom water layer, indicating the random application of fertilizers stimulate the growth of phytoplankton as discussed before.

\section{CONCLUSION AND RECOMMENDATION}

Due to the different size of the algal species: nano and net plankton forms, high abundance does not always mean a high contribution to the algal biomass and so Chlorophyceae made up only $12.14 \%$ of the annual phytoplankton biomass in the Nozha Hydrodrome, while Cyanophyceae made up $51.4 \%$, diatoms $29.55 \%$, Euglenophyceae $4.58 \%$ and Dinophyceae $2.05 \%$.

We can recommend that application of inorganic phosphorus and nitrogen fertilizers should proceed constantly in the hydrodrome but controling of 
eutrophication problems (undesirable algal blooms) should be carried out not only by reducing nutrient loading but also by management of fish habitat and fish community structure. We can recommen also to apply the statistical equations in the future to predict phytoplankton biomass in the hydrodrome.

\section{REFERENCES}

Aleem, A.A., and Samaan, A.A.,(1969). Productivity of Lake Mariut. PartlPhysical and Chemical aspects. Int. Revue ges. Hydrobiol. 54,3.313-355.Part II-Primary production. Int. Revue ges. Hydrobiol. 34(4).491-527.

Bailey-Watis, A.E.,(1976). Planktonic diatoms and some diatom silica relations in a shallow eutrophic Scottish loch-Fresh Wat. Biol. 6.68-80.

Banoub, M.W., and S.D. Wahby,(1961). Further contribution to the Chemistry and Hydrography of the Nozha Hydrodrome near Alexandria,1957-1958. Notes and Mem.,61. Alexandria Institute of Hydrobiology, U.A.R.,42 pp.

Canfield, D.E., Jr., E.Phlips, and C.M. Duarte,(1989). Factors influencing the abundance of blue-green algae in Florida lakes. Can. J. Fish. Aquat. Sci.46.1232-1237.

Claesson, A., and S.O. Ryding.(1977). Nitrogen-a growth limiting nutrient in eutrophic lakes. Prog. Water Technol. 8.291-299.

Dowidar, N.M. and A.R. Abd El-Moati,(1989). Eutrophication as a cause of fish mortality in the Nozha Hydrodrome fish farm. Alex. Comm. in Science \& Develop. Res. 25 Jan.-March.145-160.

Edler, L.,(1979). Recommendations for marine biological studies in the Baltic Sea. Phytoplankton and chlorophyll. The Baltic Marine Biologists Publication,(5).38pp.

El-Sherif, Z.M.,(1989.a). Chlorophyll a Biomass of Nozha Hydrodrome, Near Alexandria, Egypt. Bull. Inst. Public Health. Vol. XIX. 4.(4).983-991. 
Phytoplankton bimass and environmental factors in the Nozha Hydrodrome, Alexandria, 73,

El-Sherif, Z.M.,(1989b). Biomass of the standing crop of phytoplankton in Lake Burollus (Egypt). Bull.Nat. Inst. Oceanogr. \& Fish., ARE,15(1).179-189.

El-Sherif, Z.M., S.A. Shabaan, A.A. Samaan and S.M. Gharib,1994. Ecology of Chlorophyceae in the Nozha Hydrodrome. The $4^{\text {th }}$ Conf. of the Envir. Prot. is a must 10-12 May,1994.261-290.

Elster, H.J., and W.K. Jensen,(1960). Limnological and Fishery Investigations of the Nozha Hydrodrome near Alexandria, Egypt.1954-1956-Notes \& Memories,43. Alex.Inst.Hydro. U.A.R.99pp.

Gharib, S.M.,(1991). Study of the biological productivity of the Nozha Hydrodrome as a model of artificially fertilized fish farm. $\mathrm{Ph} . \mathrm{D}$. Thesis, ElUniversity, Faculty of Science Botany Dept.453pp.

Hintze, J.L.,(1993). Number Cruncher Statistical System (NCSS). Version $5.035 / 93$.

Hutchinson, G.E.,(1967). A treatise on Limnology. Vol.II, Introduction of lake Biology and the Limnoplankton. John Wielly Edit. New York,2.1115pp.

Lund, J.W.G.,(1955). Further observations on the seasonal cycle of Melosira italica (Ehr) Kutz. subsp. subarctica O.Mull. J.Ecol.42.151-179.

Lund, J.W.G.,(1965). The ecology of fresh water phytoplankton Biol. Rev.40.231-293.

Saad, M.A.H.,(1972). Investigations of the surface sediments of the Nozha Hydrodrome, near Alexandria, Egypt. Rapp. comm. Int. Mer. Medit., 20(4).515-517.

Saad, M.A.H.,(1973). Some Limnological characteristics of the Nozha Hydrodrome, near Alexandria, Egypt, Hydrobiologia, 4l(4).477-499. 
Saad, M.A.H.,(1976). Study of the core sediments of the Nozha Hydrodrome, near Alexandria, Bull. Inst. Ocean. and Fish. A.R.E 6.19-34.

Salah, M.M.,(1959). Phytoplankton population in the Nozha Hydrodrome. Notes and Memoires, 40. Alexandria Institute. of Hydrobiology, U.A.R.,19pp.

Samaan,A.A. and R.R.Abdallah,(1982). Limnological Investigation of periphyton in the Nouzha Hydrodrome. Notes and Memoires, .8, (1), Alex. Inst. of Hydrobiology, A.R.E., 107-122.

Samaan, A.A., Z.M. El-Sherif, S.A.Shaaban Dessouki and S.M.Gharib,(1994a). Nutrient salts in the Nozha Hydrodrome (Egypt) as affected by previous application of inorganic fertilizers. J.Environ. Science, Mansoura Univ., Egypt. 8.171-187.

Samaan,A.A., Z.M. El-Sherif, S.A.Shaaban Dessouki and S.M.Gharib,(1994b). Dynamics of nutrient salts between bottom sediments and adjacent water in the Nozha Hydrodrome (Egypt). Bull. Nat. Inst. Oceanogr. \& Fish., A.R.E. 20(2).85-97.

Smith,V.H.,(1983). Low nitrogen to phosphorus ratios favour dominance by bluegreen algae in lake phytoplankton. Science (Wash., $\dot{D} C)$ 221.669-671.

Vollenweider,R.S.,(1968). Scientific Fundamentals of the Eutrophication of

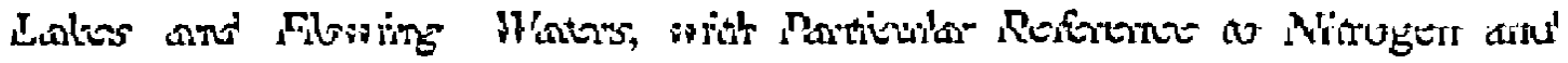
Phosphorus as Factors of Eutrophication .- Paris, Rep. Organization for Economic Cooperation and Development, DAS/CSI /68.27. 1- 192.

Wahby, S.D. and M.M.A. Shriadach, (1985). Fertilizing a large Fish pond-Nozha Hydrodrome. Rapp. Comm. Inst. Mer Medit, 29(4). 191-194.

Zaghloul,F.A., (1985). Seasonal variations of plankton in lake Nasser, Ph.D. thesis, Seuz Canal.Unniv., Fac. Sci., Zoology Dept. 
Phytoplankton bimass and environmental factors in the Nozha Hydrodrome, Alexandria, 75

Zaki, S., (1960a). Density distribution of rooted hydrophytes in Nozha Hydrodrome.Notes and Memoires, 48. Alexandria Institute of Hydrobiology, U.A.R., 28 pp.

Zaki, S., 1960 b. The effect of wind on the distribution and density of Potamogeton pectinatus in Nozha Hydrodrome. Notes \& Memoires, 44. Alexandria Institute of Hydrobiology, U.A.R., 33 pp. 


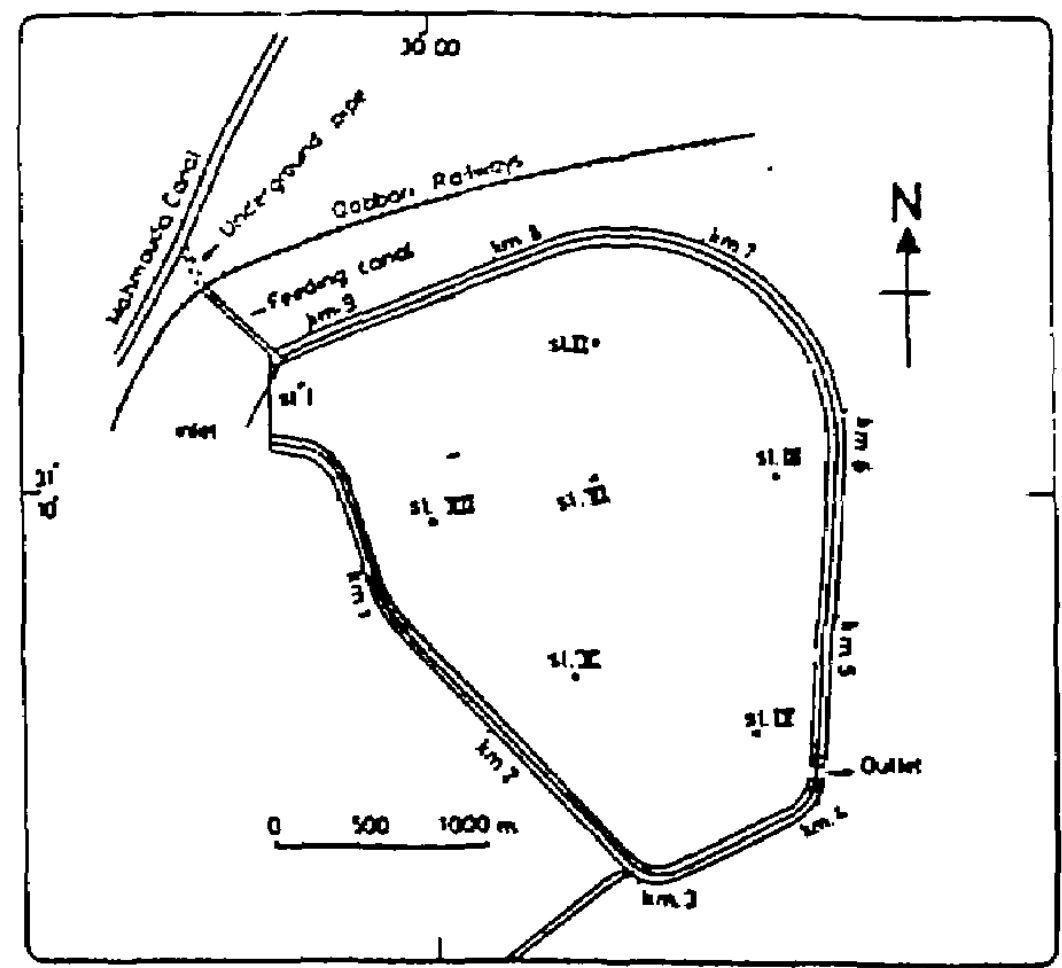

Plgure 1: Pastion of atetion 1t the Mothe Hydrodrose.

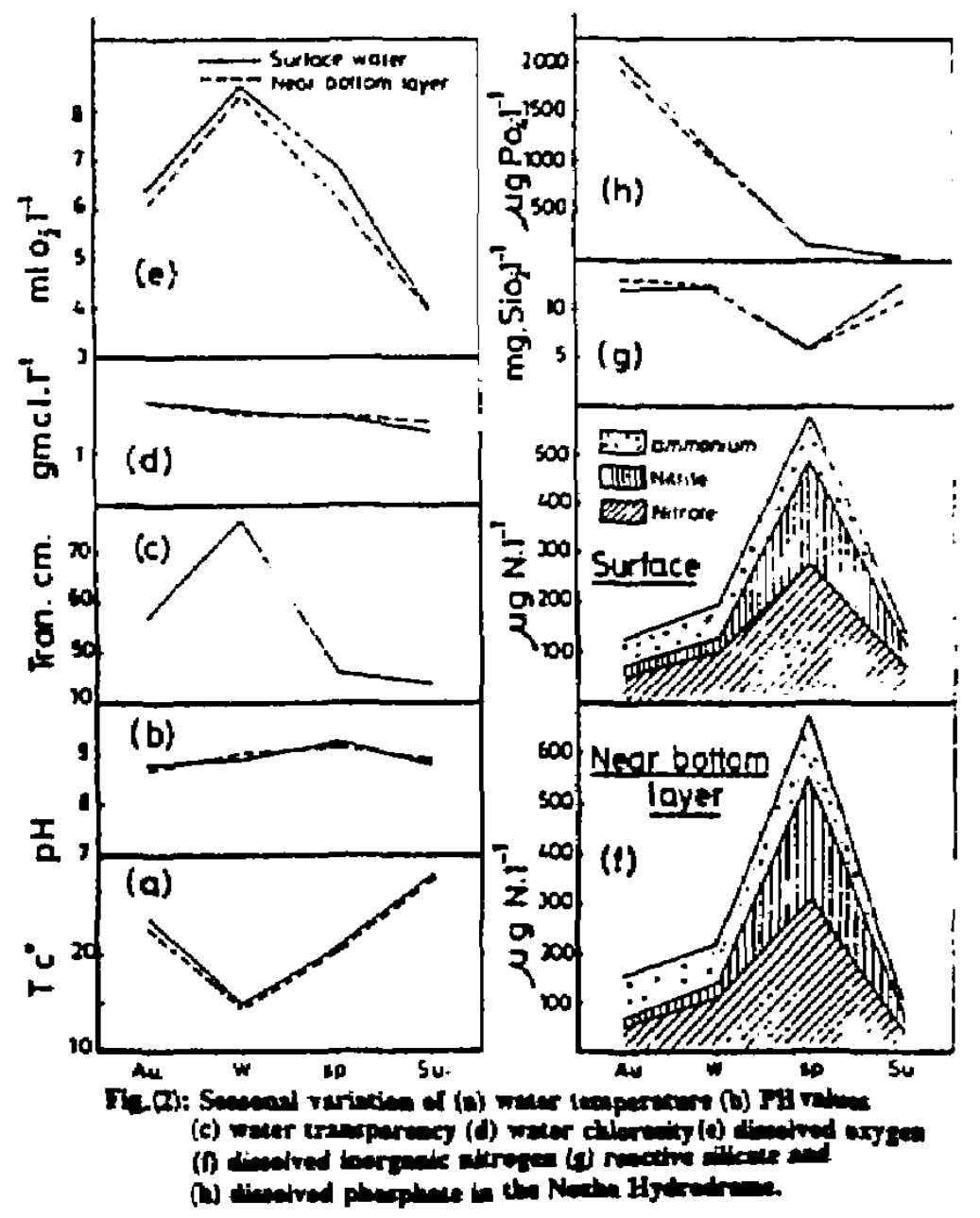




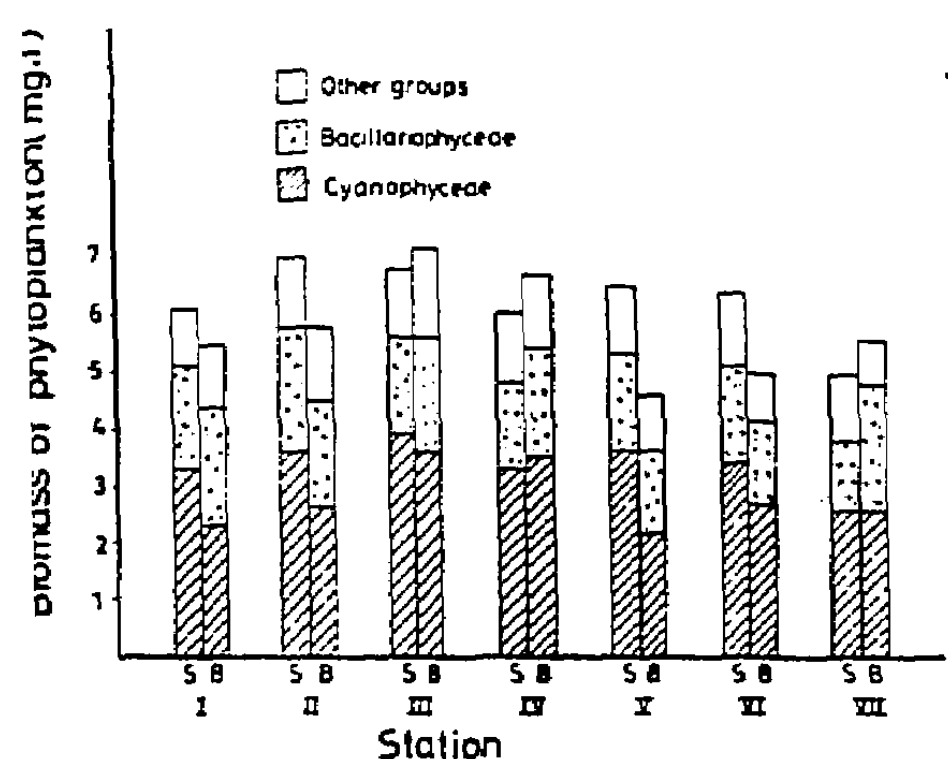

Fip.(B): Totel average of phrtopination bicones and min compoents fsssurface wrer, D: Near botion layer.
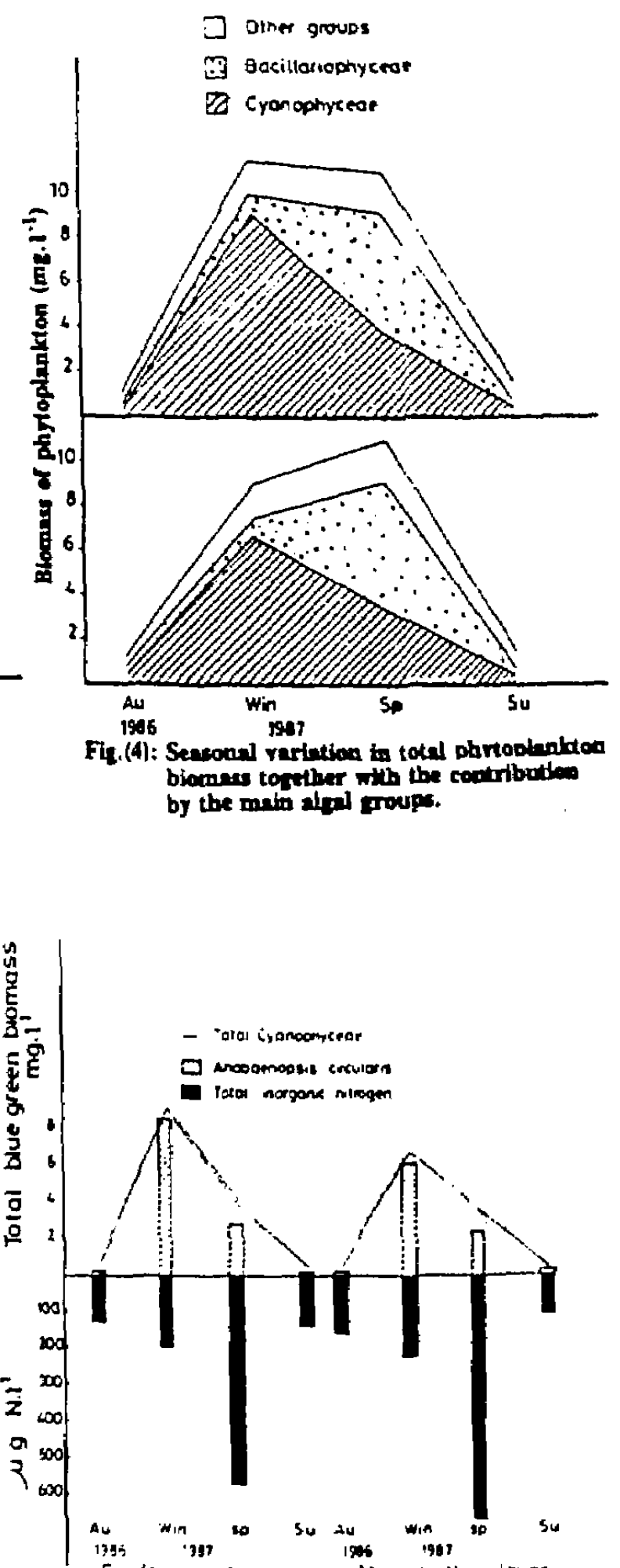

Surface water Near Dottom layer

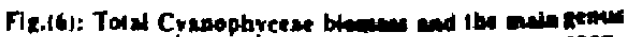

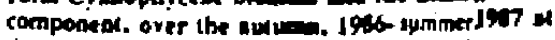

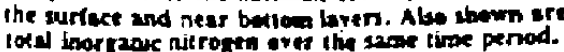




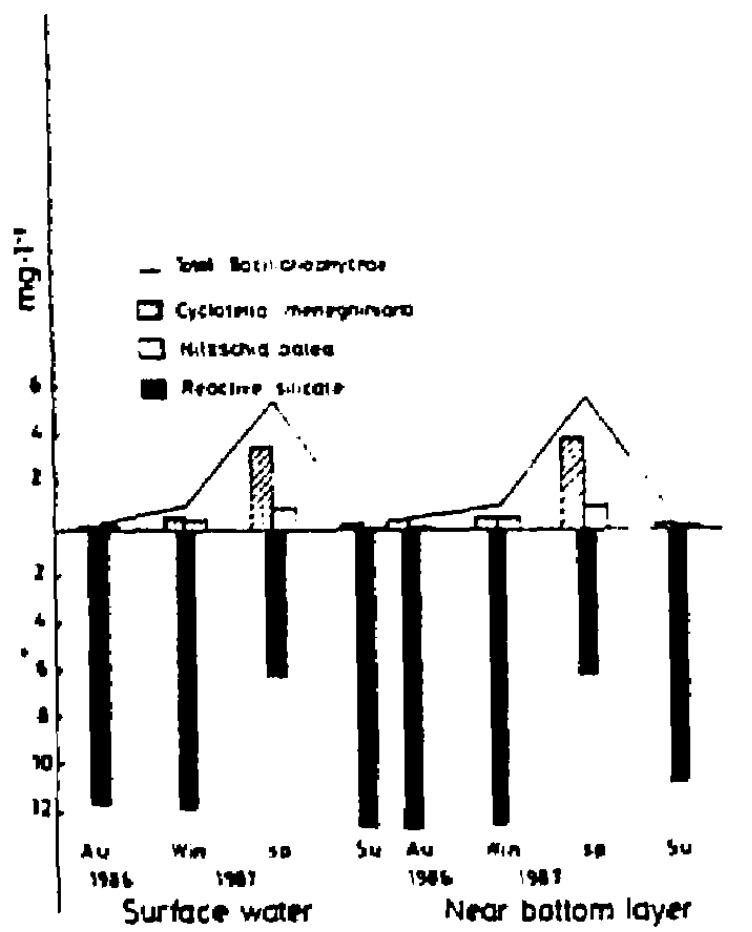

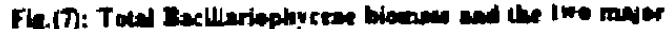

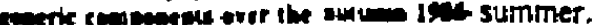

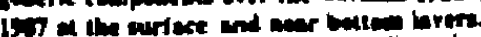

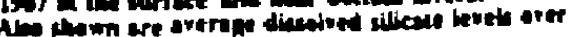

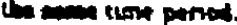
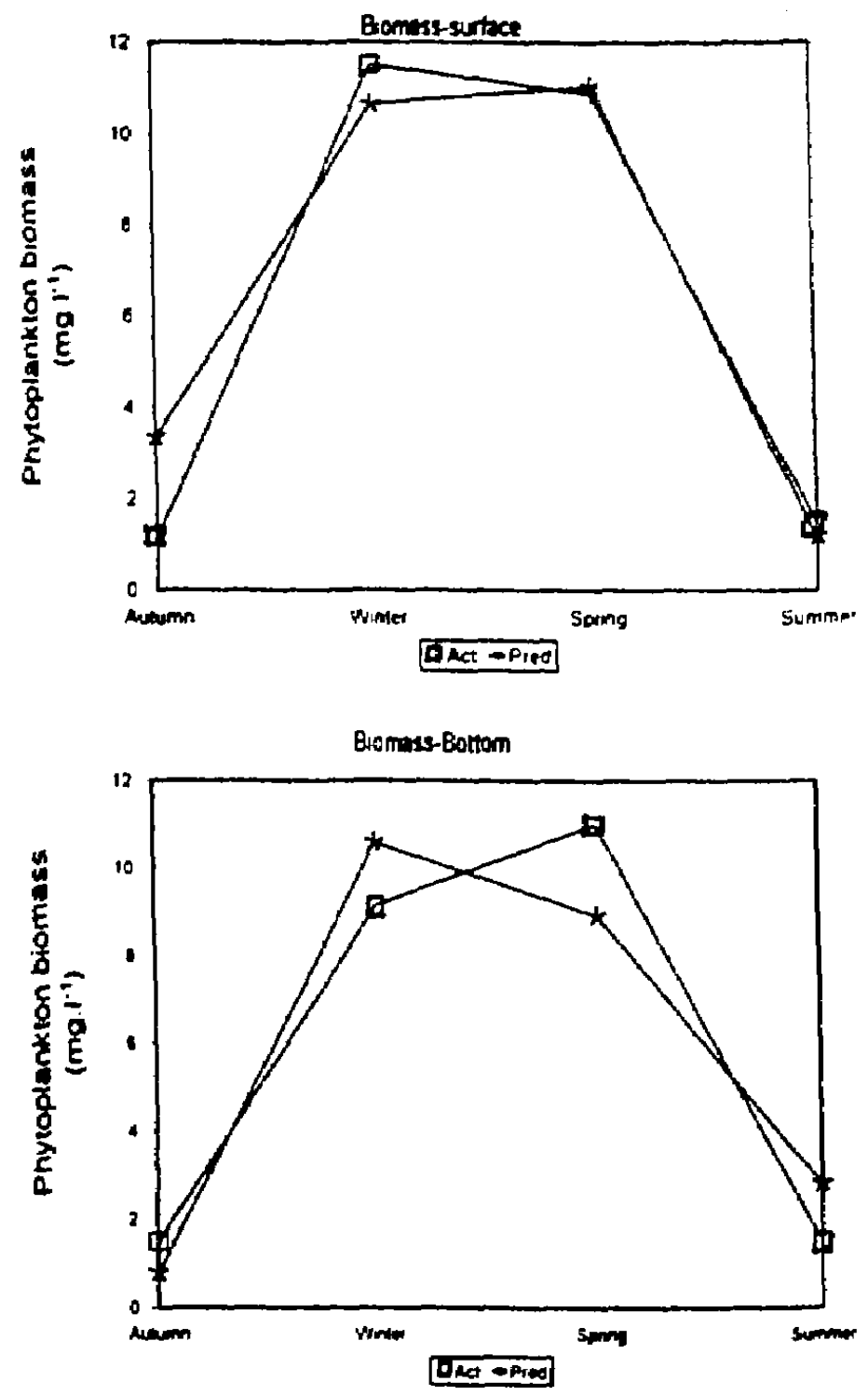

Fig. 8. Comparison of the actual phytoplankton binmass and predicted values according to the multiple regression model in the surface and near bottom water layers. 
Table (1): Average biomass (mg. $1^{-1}$ ) and numbers (thousand unit..$^{-1}$ ) of the different phytoplankton classes recorded in the surface water and near bottom layer and their percentage frequency to the total phytoplankton

\begin{tabular}{|c|c|c|c|c|c|c|c|c|}
\hline \multirow{2}{*}{ Class } & \multicolumn{4}{|c|}{ Surface water } & \multicolumn{4}{|c|}{ Near bottom layer } \\
\hline & biomass & $\Phi$ & numbers & $\%$ & bjomass & $\%$ & numbers & of \\
\hline $\begin{array}{l}\text { Cyanoph- } \\
\text { yceae }\end{array}$ & 3.3858 & 54.0 & 2,859 & 18.1 & 2.8041 & 48.5 & 2,422 & 16.1 \\
\hline Bacillari & & 27.3 & 2,253 & 14.3 & 1.8492 & 32.0 & 2,282 & 15.1 \\
\hline $\begin{array}{l}\text { phyceae } \\
\text { Chloroph }\end{array}$ & 0.7700 & 12.3 & 10,569 & 67.0 & 0.7256 & 12.6 & 10,284 & 68.3 \\
\hline $\begin{array}{c}\text {-yceae } \\
\text { Euglenop }\end{array}$ & 0.2967 & 4.7 & 82 & 0.5 & 0.2555 & 4.4 & 65 & 0.4 \\
\hline $\begin{array}{c}\text {-hyceae } \\
\text { Dinophyc } \\
\text { eae }\end{array}$ & 0.1019 & 1.7 & 10 & 0.1 & 0.1455 & 2.5 & 15 & 0.1 \\
\hline Total & 6.2653 & 100 & 15,773 & 100 & 5.7799 & 100 & 15,068 & 100 \\
\hline
\end{tabular}




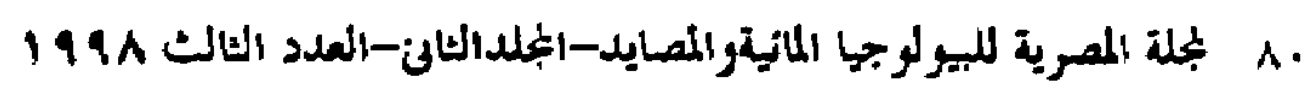

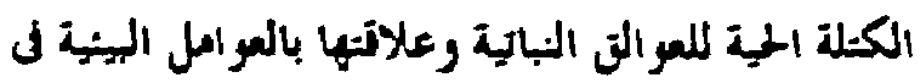

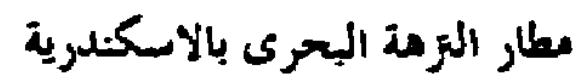

\section{ميمنة عبرد غريب

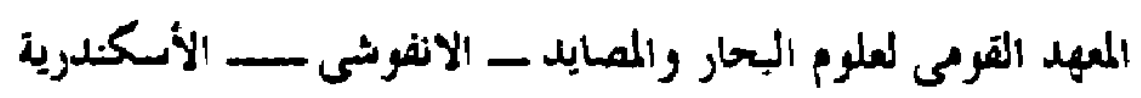

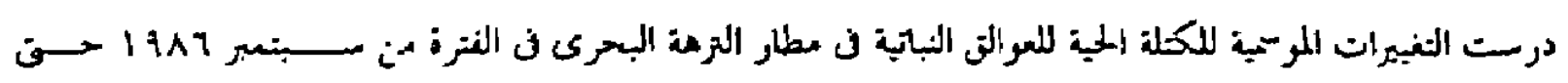

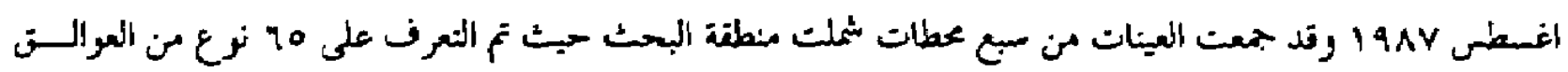

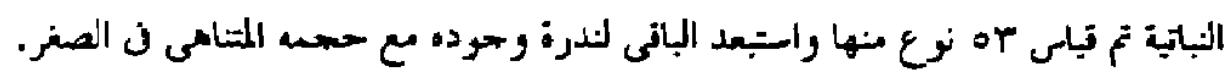

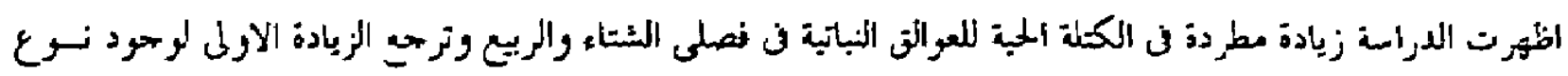

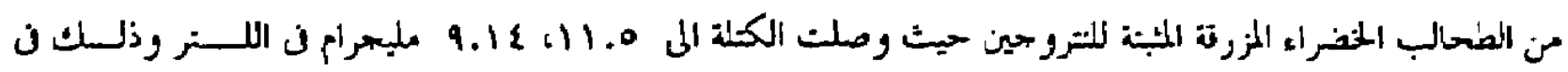

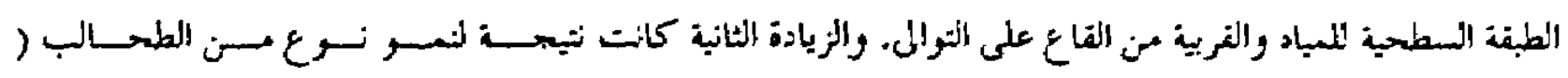

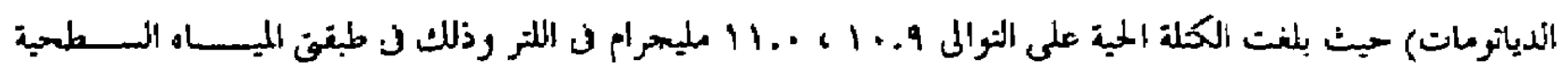
والفربية من الفاع.

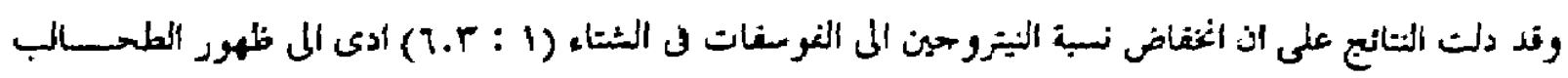

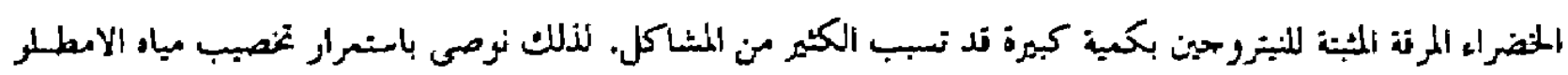

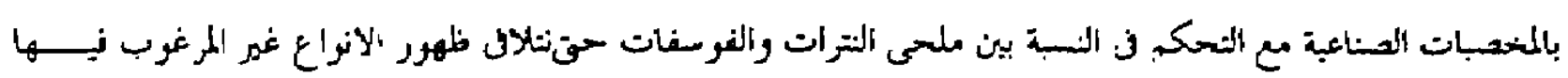

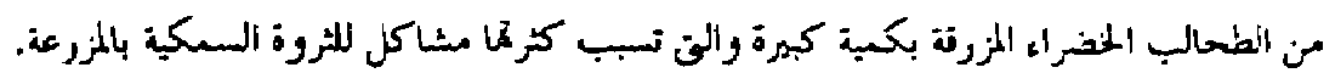

